УДК 821.163.41.09:811.135.1

https://doi.org/10.18485/msc50.2019.1.ch8

Дорин Гамулеску

\title{
ПРИСУСТВО ВУКОВИХ ДЕЛА У РУМУНСКОЈ ФИЛОЛОГИЈИ И ФОЛКЛОРИСТИЦИ ІІ ПОЛОВИНЕ ХІХ И ПОЧЕТКА XX ВЕКА
}

\section{- Важнији моменти -}

У једном кратком али лепим и полетним стилом написаном чланку, објављеном под насловом Румуни у доба Доситеја и Вука најпре у „Страном прегледу” (I, стр. 124-128), а касније (1962) прештампаном у књизи посвећеној стопедесетогодишњици смрти Доситеја Обрадовића, ${ }^{1}$ велики румунски научник светског гласа Никола Јорга први по нашем знању обраћа пажњу питањима двају додира књижевности Срба и Румуна „за време националних препорођаја на југо-истоку Европе."2 По речима Николе Јорге, први је додир почео „крајем XVIII-ог века [...] када је, жедан нових знања, путовао честити калуђер Доситије [...] и „био је гост владике Леона Геуке из Романа”, други је додир Јорга датирао „још пре 1830", када је Вук послао Асакију „читаву једну руковет румунских народних песама пронађених у Србији". Судећи данас, Јоргине оцене, старе скоро пола столећа, дају се у најмању руку употпунити, ако не, донекле, и коригирати.

У првом реду, што се Доситеја Обрадовића тиче, далеко су важнија за румунску књижевност његова дела, чији су румунски преводи, са извесним прилагођивањима, ${ }^{5}$ изашли испод пера Димитрија Цикиндеала још на почетку XIX века - неки чак и без навођења њиховог аутора - и били

${ }^{1}$ Види Српска књижевна задруга, Коло LV, књ. 370, Доситеј Обрадовић (1811-1961), приредио Младен Лесковац, Београд, 1962, стр. 74-78.

${ }^{2}$ Наведено дело, стр. 74.

${ }^{3}$ Ibidem, стр. 74.

${ }^{4}$ Ibidem, стр. 78.

${ }^{5}$ О томе, види у последње време, Мирко Живковић, Доситеј Обрадовић, у контексту српско-румунских односа, Букурешт, 1972. 
познати широј читалачкој публици, неголи Доситејева путовања и његов боравак по румунским местима, иако и они опет нису без значаја.

Са друге стране, Вукови односи са Молдављанином Георгијем Асаки, упркос њиховом честом понављању и истицању, ${ }^{6}$ засновани су једино на неким Асакијевим тврдњама и још увек су мутни, неразјашњени и, бар за сада недовољно доказани. ${ }^{7}$

Ослањајући се на касније прилоге проучавања Вукових односа са Румунима и са Румунијом, ${ }^{8}$ даћемо кратак преглед важнијих момената тог питања, посебно се задржавајући на присутности Вукових дела у румунској филологији и фолклористици II половине XIX и почетка XX века. Дозвољавамо себи да те постављене временске границе сматрамо само оријентационим. Према потреби излагања, проширићемо их и у једном и у другом правцу.

I. Када говоримо о одјеку Вукових дела код Румуна, намеће се разликовање двају периода, доста јасно оцртаних: један почиње 1837., првим до сад познатим обавештењем о Вуковом изузетно важном раду на пољу сакупљања и обелодањивања српске народне књижевности, обавештење које доноси млади у оно време Михаил Когалницеану у своме делу Rumänische oder Walachische Sprache und Literatur, ${ }^{9}$ а почетак другог

${ }^{6}$ Cf. Р. Флора, Вук и Румуни - Покушај синтезе, „Анали филолошког факултета”, св. 5, 1965, Београд, 1966, стр. 235, „Да није чланака румунског књижевника Асакија из 1848. и 1852. године [...] можда би се контакти Вукови с Румунима сматрали сасвим случајним, а споредним свакако. Овај детаљ односа Асаки - Вук је после преузиман и понављан као једина спона Вуковог интересовања за Румуне и румунска питања".

7 По обавештењима акад. М. Ибровца, изгледа да је Јорга свој чланак писао једне вечери у Београду, 1927. за време боравка на конгресу византолога. Вероватно није имао при руци потребну документацију, а писао га је по памћењу, што објашњава одређене пропусте у чланку. Сf. М. Ибровац, Један поборник румунско-југословенског пријатељства: Николаје Иорга, „Радови симпозијума о српско(југословенско-)-румунским односима (Вршац, 22-23. V 1970), Libertatea, Панчево, 1971, стр. 144.

${ }^{8}$ Најопширнији и најбогатији подацима, карактеришући се продубљеном анализом чињеница, јесу већ споменути Раду Флорин прилог и чланак I. Taloç, Vuk St. Karadžić în folcioristioa româneascâ din secolul al XIX-lea, „Revista de etnografie si folclor", XII, 1967, бр. 1, Букурешт, стр. 39-49 (Чланк је штампан и српскохрвтаски у преводу Вукосаве Карановић. Сf. Јон Талош, Вук Караџић у румунској фолклористици XIX, „Народно стваралаштво”, VI, 1967, св. 22-24, Београд, стр. 92-103).

${ }^{9}$ Види И. Талош ор. cit. У том напису, позивајући се на изванредан успех Вука Краџића, који је „својим српским народним песмама привукао на себе па- 
периода обележавају - исте 1861. године - двојица румунских књижевника, G. Sion ${ }^{10}$ и Al. Odobescu, ${ }^{11}$ који у својим упоредним фолклористичким студијама уводе у научни саобраћај Вукова дела. Осим Когалницеануа, у првом периоду су објавили податке о Вуковој делатности и други истакнути румунски књижевници тог времена, као што су I. Heliade - Râdulescu, ${ }^{12}$ G. Baritin, Г. Асаки. У свим тим информацијама као прва Вукова заслуга, подвлачи се његов рад на сакупљању српског фолклора, а тек после тога израда граматике и речника. То одговара растућем ин-

жњу културне Европе”, Kogäliceanu истиче важниост и потребу сакупљања и објављивања румунског фолклора.

${ }^{10}$ Cf. G. Sion, Despre literature sîrba în raport cu cea româna (О српској књижевности у односу на румунску), „Revista Carpatilor”, II, 1861, стр. 501-525.

${ }^{11}$ Cf. Al. Odobescu, Cîntecele populare ale Europei râsâritene, mai cu seamâ în raport su Cara, istoria si datinele românilor (Народне песме Источне Европе, нарочито у вези са земљом, историјом и обичајима Румуна), „Revista româna”, I, Букурешт, 1961. На стр. 28 Odobescu, у једној фусноти, даје детаљна обавештења о преводима Вукових народних песама. И. Талош, ор. cit., тумачи то као доказ колико је добро био упознат Одобеску са делатношћу. А да то не поричемо изражавамо мишљење да су се Румуни упознали са Вуковим делима углавном преко превода и то донекле објашњава релативно касну реакцију на његову делатност коју су боље сагледали тек у петој деценији прошлог века (Чланци Барица и Асакија о српској књижевности).

12 У ствари, ради се о једној краткој вести (по мишљењу проф. Р. Флоре, ор. cit., стр. 254 „Вест је свакако репродукувана из аустријских новина, а њен извор тамо јамчно је Копитар”) објављеној под насловом „Austria” у Heliadeovom листу „Curnerul românesc” (27) 3. IV. 1824. У њој се обавештава о одликовању Вука златном медаљом као уздарјем за збирку народних песама коју је поклонио руском цару. (Садржај вести види код Вукосаве Карановић, Вук Караџић и Румуни, „Библиотекар”, Београд, XVI, 1964, 6р. 1-2, стр. 12 и Р. Флоре, ор. cit., стр. 254). На први поглед случајна, вест је ипак важна, ако водимо рачуна о томе да се у њој истиче колико је високо оцењено сакупљање фолклора и о личности I. Heliade - Râdulescu-a. Довољно је да споменемо да је I. Heliade - Râdulescu-a (1802-1872) једна од најистакнутијих културних личности Румуније у првој половини XIX века. Књижевник, критичар, филолог, политичар, он је главни аниматор и иницијатор на књижевно-културном пољу у епоси формирања модерне румунске културе. Између осталог, основао је „Књижевно друштво” (1827), аутор је и преводилац многобројних уџбеника, оснивач штампарије, издавач првог румунског листа (1829), аутор румунске граматике (1828) у којој предлаже упрошћавање ћирилске азбуке од 43 на 30 знака, доказује супериорност фонетске ортографије над етимолошком, ставља у основу књижевног језика којим народ говори. Све ово, као и успео и интересантан реферат проф. Хоралека на овом скупу, показује колико би била интересантна једна типолошка студија на тему Вука и Хелиадеа. 
тересу који манифестују Румуни, међу њима на првом месту Ал. Русо и В. Александри, према румунском народном стваралаштву. У том смислу, у праву су они који сматрају да је Вук дао подстрек акцији Румуна за сакупљање својих народних умотворина. ${ }^{13}$ То важи утолико више уколико је сигурно да се најважнији од првих сакупљача румунског фолклора, B. Alecsandri ${ }^{14}$ упознао са француским преводима народних песама Вука Караџића. ${ }^{15}$ У другом издању својих румунских народних песама Alecsandri чак даје извод Зидаюе Скадра. ${ }^{16}$

Иначе, већ поменути G. Baric, у свом напису о српској књижевности Ceva pentru literatura serbianâ ${ }^{17}$ („О српској књижевности) у којем хвали збирке Вука и Михајловића, које су, на велику част Срба, преведене на немачки, француски и енглески, отворено изражава наду да ће ови „успеси наших суседа подстакнути и Румуне." 18

Најпознатији од свих досадашњих написа о Вуку Караџићу свакако је чланак Молдављанина Г. Асаки, и то не толико по својој садржини, која је изван сваке сумње интересантна, колико по једној фусноти уз тај чланак. Изгледа да је повод Асакијева чланика од 1848. једно писмо Н. В. Цара Аустрије упућено принцу Дитрихштајну у вези са даривањем једног прстена Вуку Караџићу, јер у наставку својег кратког написа, Асаки репродукује то писмо „Које објављују новине” и испод њега ставља, „Беч 11. јануара 1848". Чланак носи наслов literatura sîrbeascâ (Српска књижевност $)^{19}$ и, после топлих речи о пријатељским односима између Срба и Румуна и о њиховој заједничкој борби за независност, говорећи чак о њиховј заједничкој судбини, наставља: „Међу неколицином српских књижевника најважнији је Вук Стефановић Караџић.” Даље Асаки говори са топлином о Вуку и његовој делатности и истиче: „Он [Вук] је рекао „Ако се хоће просвећивати људи, потребно је да им се говори на њихо-

${ }^{13}$ Cf. N. Iorga, op. cit, стр. 78. Он, међутим, сматра сигурном чињеницом да је Вук сакупио и румунски фолклор. Види о томе, даље.

14 Cf. V. Alecsandri, Poezii populare, balade, cîntece bâtrîneçsti, I, 1852.

15 I. Talos, op. cit., сматра да је то упознавање ишло преко превода Elise Volart, Chants populaires des Serbiens, I-II, Paris, 1834. Иначе Талош налази доста сличности између Вука и Alecsandri-a.

16 Друго издање је изашло 1866. Види, о томе, и I. Taloš, op. cit. Превод те песме у целини даће нешто касније G. Dem. Teodorescu y Poesii populare române, Букурешт, 1885, стр. 470-473.

${ }_{17}$ Cf. „Foaie pentru minte, inimâ ši literatura”, Брашов, 1843, стр. 216.

18 Види I. Taloš, op. cit.

19 Чланак је објављен у Асакијевом часопису „Albina româneasca”, Јаши, XX, бр. 6 од 18. I. 1848., стр. 21-22. Наводе дајемо по издању N. A. Ursu-a: Gh. Asaki, Scrieri literare, tom. 1-2, Editura de stat pentru literatura si arta, Bucurešt, 1957. 
вом језику". Зато је истражио све словенске земље, сакупио је и уредио народне песме, саставио је српски речник и [описао је] народне обичаје [...] За кратког периода основана је нова српска књижевност, свежа као сена џиновског кедра; под њом одмара Вук, његови сународници полажу венце на његове ноге, а будућа поколења ... Али не, нека живи, нека живи за толико лепу ствар!”20 Што се саме ствари Вука Караџића тиче, Асаки је мање прецизан када оцењује да је Вук отишао у свет да тражи „лековите елементе” против „турског јарма и мрака” који су тискали његову нацију и да „Отада захвална илирска отаџбина [...] са поштовањем изговара име оног мужа који је знао да удахне у становнике оних земаља искру моралних светлости". 21 Томе додајемо још и Асакијево мишљење да „Из Вуковог органа (sic!) Срби [...] су разумели шта су, шта могу бити, шта дишу и каква их будућност очекује”."22 Јасно је да све ово више личи на Асакијево разумевање ствари него ли на Вуково. ${ }^{23}$

Пре него што бисмо се задржали на садржају споменуте фусноте уз тај чланак, да поменемо још неке прилоге познавања Вукових дела и његове делатности код Румуна.

Почетком друге половине прошлог века написи, информације и оцене о Вуковом раду постају све чешћи. Тако, на пример, Трансилванац Timotei Cipariu - свакако на основу Вуковог фолклорног материјала - оцењује ${ }^{24}$ да су песме о Урошу и Краљевићу Марку сличне као јаје јајету румунским епопејама и да су Срби претекли Румуне у објављивању фолклора. ${ }^{25}$

У Сибињском часопису „Telegraful român”, ${ }^{26}$ који развија и значајну акцију за сакупљање и објављивање румунског фолклора, Pavel Vlasici има прилику, 1859., два пута да говори и Вуку Караџићу. У првом напису подсећа да „Знамо какво је узбуђење створило издавање оваквих српских песама" (мисли се на немачке преводе Вукових песама), ${ }^{27}$ а у дру-

${ }^{20}$ Gh. Asaki, op. cit cit., том 2, стр. 340-341.

21 Idem, ibidem, стр. 340.

22 Idem, ibidem, стр. 341. Интегрални текст на српскохрватском Асакијевог чланка, као и писмо Ditrichstelnu, види код Вукосаве Карановић op. cit.

${ }^{23}$ О Асакијевом односу према фолклору, види A1, Bistriteanu, G. Asaki si folclorul, „Limba si literatura”, Bukurešt, I, 1955.

24 Види „Foaie pentru minte, inima ši literatura”, Брашов, 1955, стр. 118.

25 Исп. I. Taloš, op. cit.

26 Тај је часопис основао и њиме руководио трансилвански митрополит Andrei Saguna од чијих су се односа са Вуком сачувала два писма. Cf. T. Bod’ogae, Aus dem Briefwechsel Saguna's mit Vuk Karadžić, „Revue des études sud-est européennes”, VI, 1966, бр. 3-4, Букурешт, стр. 593-601.

27 Ap. I. Taloš, op. cit. 
гом доказује како нас Румуне „ништа не може представити у културном свету [...] као што могу ове [народне] песме, коледе и све што је слично томе”, и то подржава позивајући се опет на дубоки „утисак које је оставила у страној књижевности збирка српских народних песама које је сабрао Вук Стефановић" и које је Талфи превела на немачки. ${ }^{28}$

Именима румунских истакнутих књижевника и филолога XIX столећа који су познавали Вуков рад и дело можемо додати још В. P. Hasdeua, ${ }^{29}$ M. Eminescu-a, ${ }^{30}$ Al. Marienescu-a, M. Gastera, G. Panu-a, T. Maiorescu$\mathrm{a}^{31}$ и многе друге, али се на њима нећемо специјално задржати. Казаћемо само то да су они сви одавали признање Вуковом раду и високо ценили лепоту усменог народног стваралаштва српског народа.

Пре него што бисмо прешли на други аспекат Вуковог присуства у Румунији, да наведемо још одломак некролога који је спонтано написао Tincu Velea приликом Вукове смрти: „Овај човек је управо у време док сам писао ове редове умро у Бечу. Он је себи ставио за животни циљ да се спусти до дна народне душе, и одатле да извуче на видело одору која је скупоценија од злата и драгог камења. Због тога најбољи умови свих нација оплакују преминулог, јер народи су збратимљени кад су у питању њихови оправдани захтеви и не питају за језик, националност, веру земљу ... спољни изглед, него више гледају на разум и заслуге које има човек од науке, на добро народа". ${ }^{32}$

${ }^{28}$ Idem, ibidem. O интересу Румуна за фолклор народа Југославије, израженом у румунској штампи XIX века, види Еуген Маринеску, Interesul pentru folklorul popoarelor jugoslaviei in presa româneasca din secolul al XIX-lea, caonштење на Симпозијуму о српско (југословенско) - румунским узајамностима у области народне књижевности. Панчево, 29. IX - 1, X. 1972. Cf. Societatea de limba româna din P. S. A. Voivodima, Un deceniu de activitate (1962-1972), Зрењанин, 1972, стр. 71.

${ }^{29}$ Hasdeu је српске народне песме које је Вук објавио употребљавао у научним истраживањима, а у његовом часопису Dinosie Mitona. Види, о томе, даље „Train”, штампао је 16 српских балада у преводу.

${ }_{30}$ Октав Паун покушао је да докаже, у једном за сад необјављеном реферату, да, поред тога што је надгледао превод српских песама на румунски, Eminescu се инспирисао из Косовског циклуса у једној својој врло познатој песми. Тешко је, међутим, примити и једну и другу Паунову претпоставку. Cf. Octav Paun, Mihail Eminescu si eposul iugoslav - Serisoarea a III-a, чији резиме види у књизи Симпозијума о српско(југословенско)-румунским узајамностима у области народне књижевности, Саопштења (резимеи), Панчево, 28. IX-1. X 1972.

31 Детаљније о овој последњој четворици види код I. Taloš, op. cit.

32 Фуснота у књизи Istorioara bisericeasca politico-nationala, 1865, стр. 284. Ap. I. Taloš, op. cit., (у преводу Вукосаве Карановић). 


\section{II. Најпознатији и највише коментирани моменат Вукових односа са} Румунима остао је до данас, свакако, однос Вук - Асаки. У већ споменутој фусноти из 1848. и у једном напису поводом објаве Александријеве збирке румунских народних песама из 1852, између осталог, Асаки тврди да је од Вука примио румунске народне песме, а то би значило да се Вук бавио сакупљањем румунског фолклора. Текстови ових Асакијевих написа су објављени и на српско-хрватском ${ }^{33}$ али сматрамо потребним за наш коментар да их и ми овде наведемо. За већу прецизност навешћемо како оригиналан текст на румунском, тако и превод на српскохрватски:

\section{a) Текст фусноте}

La acel prilej d. Vuk adunasa in calatoriile sale o multime de cîntece nationale române, care mi le daduse spre a adaogi colectia cîntecilor de mine adunate su scop de a le publica, care însa toate au ars la Iasi in focul cel cumplit din anul $1827 .{ }^{34}$

\section{б) Текст који се односи}

Inca la 1822, in epoha emigratiel, calatorind prin provintiile de români locuite, eu am fost intreprins pentru asemenea scop a aduna a lor cîntice, iar la 1823, cînd petreceam la Viena, mult onorabilul d. Vuk Stefanovici, renumitul literator sîrb si al meu amic, carele calatorise multi ani prin provintiile sud-slavice spre adunarea cînticelor sîrbesti, ce apoi ga 1823 le-au tiparit în 4 tomuri la Lipsca, cu cheltuiala printului Milos, au fost adaogit colectia me, daruindu-mi 30 coale manuscrise cintice românesti, care su ocazia calatorilor saxe le-au fost adunat in Transilvania, in Banat si Tara Romãneasca, si intre care se atlau compuneki foarte interesante. Dar colecta, cu multe a mele, le-au mistuit în Iasi focul anului 1827, încît acele cîntari ramasera iar numai în gura poporului, ca melodia patetica in fluierul pastorilor, iar adunarea lor in sarcina literatilor mai ferice de a le asigura de urgia timpului si a evenimentelor. ${ }^{36}$
Том приликом г. Вук је био сабрао у својим путовањима мноштво националних песама, које је мени дао да бих допунио збирку песама које сам ја сакупио, али су све изгореле у Јашима у страхотном пожару из 1827. године.

\section{на Вука у чланку из 1852}

Још 1822., у епоси миграције, ${ }^{35}$ путујући кроз провинције настањене Румунима, ја сам себи ставио за циљ да сакупим њихове песме, а 1823., када сам се налазио у Бечу, многопоштовани г. Вук Стефановић, чувени српски књижевник и мој пријатељ, који је дуго година већ био путовао по јужнословенским провинцијама да би сакупио српске песме, које је затим 1823. штампао у Лајпцигу у 3 тома, о трошку кнеза Милоша, допунио је моју збирку, подаривши ми 30 рукописних листова (табака) румунских песама, које је приликом својих путовања сабрао у Трансилванији, у Банату и у Влашкој, и међу којима су се налазили врло интересантни састави. Али збирка заједно са много мојих, изгорела је у јашком пожару године 1827., те су оне песме остале опет само у устима народа, као патетична мелодија у пастирској фрули, а њихово сакупљање у задатак књижевника срећнијих у њиховом обезбеђењу од напасти времена и догађаја. ${ }^{37}$

33 Види Г. Добрашиновић, Пасионирани сакупљач народног блага, „Политика”, XLI, бр. 18.070 од 26. I. 1961, стр. 10; Вукосава Карановић, Вук Караџић и Румуни, „Библиотекар”, XVI, 1964, бр. 1-2, Београд, стр. 12-13. Исп. и Р. Флора, op. cit., стр. 254, фусноте 62, 63.

34 Види „Albina româneasca”, XX, 1948, Јаши, бр. 6 од 18. I. стр. 21-22.

35 1821-1822, за време Етерије, Асаки је емигрирао у Бесарабију и Буковину.

36 „Gazeta de Moldavia”, XXIV, 1852, Јаши, бр. 20, стр. 77.

37 У преводу смо настојали да сачувамо Асакијев стил и чак и неке његове нејасноће у изражавању. 
Одмах ћемо приметити да је главна идеја двају написа не та да се Вук Караџић бавио сакупљањем румунског фолклора, него та да се тим послом бавио сам Асаки, који је већ 1822. поседовао збирку румунских народних песама. ${ }^{38}$ Вук има ту више улогу сведока јер, ето, познавајући Асакијеве намере да објави већ сабрану своју збирку, поклања му 1823. румунске народне песме које је сам сабрао. ${ }^{39}$

Интересантно је да су истраживачи преузели из Асакијевих навода само споредну тврдњу, а главну су потпуно занемарили. Илустративна је у том погледу интерпретација Николе Јорге: „пре свију једино г. Асаки је имао у рукама оригиналне румунске народне песме и то захваљујући Вуку који их је сакупио" зивању - за првог сакупљача румунског фолклора Вука а не Асакија. ${ }^{41}$

И стварно има разлога да се Асакију не поверује да је поседовао збирку фолклора, који је сам сабрао.. ${ }^{42}$ Питање је да ли му треба поверо-

38 Да је хтео да подвуче Вукову преокупацију за сакупљање румунског фолклора, логично би било да то наброји међу Вуковим заслугама те врсте у самом тексту, а не у фусноти. У вези с тим треба приметити да је 1848. Александри већ предао у штампу своју збирку, а у Асакијевом Алманаху за исту годину објавио једну румунску народну песму. (Види о томе E. Lovinescu, Gheorghe Asaki - viata si opera lui, Букурешт, Cartea româneasca, 1921, стр. 197).

39 У напису из 1852. који носи наслов Poezii populare, balade, cîntece batrînesti adunate de d. V. Alecsandri, partea I tiparita la Buciumul român, Александријевој збирци је у ствари посвећено врло мало пажње. Од укупно 32 реда, колико броји напис у издању Н. A. Ursu-a, у 18 редова Асаки говори о својој збирци фоклора коју је он имао већ 30 година пре Александрија али коју није имао срећу да изда, и о присним односима са Вуком Караџићем, дајући тачнији опис рукописа који је од Вука - како он каже - примио.

40 Cf. N. Iorga, Istoria literaturii române, Букурешт, 1925, стр. 318.

41 Исту оцену налазимо и код Вукосаве Карановић, op. cit.

42 То може да чини предмет специјалног испитивања. Ограничићемо се на набрајање важнијих података. Прво, биографи Асакија и истраживачи његовог дела нису наишли ни на какву његову фолклорну преокупацију осим што су му неки народни мотиви послужили као извор књижевног надахнућа (cf. Al. Bistriteanu, op. cit.). Друго, међу радовима који су му изгорели у пожару није споменута и наводна збирка румунских народних песама. То Асаки чини - необјашњиво изван контекста који смо споменули - тек више од две деценије касније. (Међу важнијим рукописима који су му изгорели 1827. споменути су преводи трагедија Alizira и Saul, оригинална трагедија Mihaiu-Voda Viteazul, једна историја Римског царства, лирски стихови, курс математике и збирка басана Cf. E. Lovinescu, op. cit., стр. 37, где се наводи „Curierul românesc”, бр. 31 од 26/7 јула 1829., допис из Јашија, датиран 4. јула.) Трећи се разлог тиче психичке природе Г. Асакија. Вуков савременик и скоро и вршњак, Г. Асаки (1788-1869), кул- 
вати и онда када тврди да је примио румунски фолклор од Вука. У том погледу код истраживача сусрећемо четири става:

a) Једни примају без резерве аутентичност изјаве. Међу њима N. Iorga, ${ }^{43}$ Л. Павловић, ${ }^{44}$ L.[ucia] D.[emetrius], ${ }^{45}$ Г. Добрашиновић, ${ }^{46} \mathrm{M}$. Gheorghievici, ${ }^{47}$ В. Карановић, ${ }^{48}$ M. Anghelescu, ${ }^{49}$ и многи други. То је најраспрострањенији став судећи по томе што и у недавно објављеном румунском енциклопедијском речнику чланак посвећен Вуку Караџићу завршава речима: „Сабрао је и румунски фолклор”. ${ }^{50}$

турна личност енциклопедијског образовања, доминирао је у Молдавији прве половине XIX века цео културни живот. Књижевник, историчар, математичар, професор, сликар, Г. Асаки је организатор и оснивач школа, оснивач првог молдавског листа „Albina româneasca” (1829), иницијатор важнијих културних подухвата и манифестација на румунском језику. Али „његова улога завршава се 1848. После овог датума Асаки постаје анахронизам” (Е. Lovinescu, op. cit., стр. 231). Човек „који је за књижевност Молдавије учинио више него сви Молдављани заједно”, како је писао Когалницеану 1840. (Cf. D. Caracostea, Izvoarele lui G. Asaki, Букурешт, 1928, стр. 5), није, међутим, могао лака срца да се задовољи са споредним местом. Има доказа да је Асаки „под старост волео да себи препише све славне подухвате прошлости" (George Sorescu, Gh. Asachi, Editura Minerva, Букурешт, 1970, стр. 77), али и неке друге његове изјаве из млађих година према којима је добио звање доктора филозофије и Диплому инжењера и архитекта на Универзитету у Љвову нису се обистиниле. Cf. Stefan Birsanescu, Gheorghe Asachi si studiile sale la Universitatea din Lwos, „Iasul literar”, nr. 7, iulie 1957, стр. 107-111. Cf. i George Sorescu, op. cit., стр. 31.

43 Види горе.

44 Исп. Л. Ст. Павловић, Румунска народна песма, „Прилози проучавању народне поезије”, Београд, I, 1935, стр. 38 (Ап. Р. Флора, ор. cit., стр. 235).

${ }^{45}$ L.[ucia] D.[emetrius], Vuk Stefanović Karadjic [sic!] (1787-1864) - parimetele limbii sîrbe moderne, „Viata româneasca”, XVII, 1964, бp. 9, септембар, Букурешт, стр. 176.

46 Op. cit.

47 Cf. M. Gheorghievici, Vuk Stefanović Karadžić si românii, „Limba si literatura”, XIII, 1967, Букурешт, стр. 60-61.

48 Op. cit.

49 Cf. Mircea Anghelescu, Serbia si sîrbii în presa si literature româna, Радови Симпозијума о српско(југословенско)-румунским односима (Вршац, 22-23, V. 1970), Libertatea, Панчево, 1971, стр. 31.

50 Academia Republicii Populare Române, Dictionar enciclopedic român, vol. III (K-P), Editura Politica, Букурешт, стр. 13. 
б) Други истраживачи, пошто изражавају одређене сумње, до краја ипак примају Асакијеву изјаву за аутентичну. Навели бисмо Al. Bistriteanu- ${ }^{51}$ и prof. Radu Flora. ${ }^{52}$

в) Трећи истраживачи, међу којима N. A. Ursu, ${ }^{53} \mathrm{I}_{\text {. Talos }}{ }^{54}$ и - слободни смо да кажемо - аутор ових редова, сматрају питање нерешено.

г) Једино један аутор - по нашем знању - одлучно одриче аутентичност Асакијеве тврдње да је од Вука примио румунске народне песме. ${ }^{55}$

И сумње у аутентичност ових Асакијевех навода су оправдане. У првом реду, у њима има извесне противуречности ${ }^{56}$ и нетачности ${ }^{57}$,

51 Op. cit.

52 Op. cit., стр. 242: „Има стварно и разлога за сумњу: а) чињеница је да о неком пријатељству или чак и обичном познанству [између Асакија и Вука] нема никаквог трага у Вуковим биографијама; б) о томе нема трага ни у Асакијевој биографији, па чак ни у аутобиографијама или написима које је он сам редиговао; в) о томе нема речи ни у кореспонденцији једнога или другога (што не значи, опет, да се то не може још открити); г) фолклористичке преокупације Асакијеве (осим његове, по сопственим речима, уништене збирке у Јашком пожару) нису никакве; може се једино говорити о некој фолклорној инспирацији са реперкусијама на његово књижевно стваралаштво.

Ипак сматрамо Асакијеву изјаву за аутентичну, бар онај њен део који се односи на Вука, јер, ако ништа друго, он није могао измислити детаље и дати прецизан опис непостојећег свежња Вукових румунских народних песама".

${ }^{53}$ N. A. Ursu y Предговору свог издања том. I, стр. 28 изражава се обазриво: „Асаки изјављује да ..., а да се не ангажује нити за један нити за други став.

${ }^{54}$ Сматра се да је питање Асакијевих веза са Вуком тешко разрешити, и да то могу учинити једино југословенски истраживачи. Уколико би се Асакијеве тврдње доказале аутентичним, Талош, op. cit. се слаже са Румуном Caracostea да песме потичу од Румуна у Србији.

${ }^{55}$ Cf. G. Mihaila, 100 de ani de la moartea marelui filolog si folclorist sîrb Vuk Stefanović Karadžić „Luceafarul”, Revista a Uniunii Scriitorilor din R. P. R., VI, бp. 22 (155), 24. октобра 1964., Букурешт, стр. 12. G. Mihaila одбацује аутентичност тврдње Г. Асакија који је „Објавио још хронику коју је сам патворио и чија је неаутентичност касније доказана”. „Вреднија са документарног гледишта, остаје топла оцена коју је Асаки дао великом српском филологу и фолклористи.

56 Тако, на пример, у напису из 1848. Асаки тврди да је примио „мноштво („o multime) румунских националних (sic!) песама, а у писму из 1852. прецизиpa „30 рукописних листова (табака)” („30 coale manuscrise”), што није сасвим свеједно.

57 Асаки тврди, на пример, да је Вук румунске народне песме „приликом својих путовања сабрао у Трансилванији, Банату и Влашкој. Међутим нема ни трага од каквог Вуковог путовањас по Влашкој, а што се Баната тиче, где је Вук више пута био, не зна се ништа о Вуковом интересовању за румунски фолклор. 
доказане као такве, а у другом реду, упркос уложеним напорима није пронађена ниједна сигурна потврда нити Вукових преокупација за румунски фолклор, нити његовог познанства са Асакијем (некмоли неких приснијих, пријатељских односа). Једина чињеница која наводи истраживаче да ипак прихвате аутентичност Асакијевих изјава у вези са Вуком остаје то да су оне дате још за времена када је Вук живео ${ }^{58}$. Али, као што смо већ рекли, нису нађене - бар до сада - нити потврда, нити негација Асакијевих тврдњи. Све што је на ту тему писано, упркос богатом материјалу и исцрпној анализи, остаје у кругу хипотеза ${ }^{59}$. И има доста изгледа да то за увек остане тако ${ }^{60}$.

III. Указали смо већ на то да важан моменат присуства Вукових дела у Румунији обележавају упоредне фолклористичке студије Ал. Одобре-

Види лепу и аргументовану дискусију код проф. Р. Флоре, op. cit., стр. 238-239, 242. Зато испитивачи нису узели у обзир области на које је указао Асаки, него су једино локализирали румунски фолклор у могућној Вуковој збирци било у Банату Cf. Г. Добрашиновић, op. cit.), било у Источној Србији (cf. I. Taloš, op. cit.; Al. Bistriteanu, op. cit., стр. 16, сматра да је Вук сакупио румунске народне песме између 1811-1813, у североисточној Србији од тамошњих Румуна. Али, као што примећује и M. Gheorghievici, op. cit., стр. 58, за време боравка у Кладову Вук још није имао фолклористичка интересовања. По Gheorghievici-u, Вук је почео да сакупља румунски фолклор 1819., када је, на путу из Русије, боравио у Кишињеву, а затим у Јашима. Али у недостатку сваког доказа и та Gheorghievicieva тврдња остаје проста претпоставка). Р. Флора, ор. cit., стр. 243-244 наводи као веројатнију хипотезу да је Вук наведене румунске песме могао примити од једног од својих кореспондената и наводи Сару Михаилову Карапанџић.

${ }^{58}$ Cf. I. Taloš, op. cit., Al. Bistriteanu, op. cit.

${ }^{59}$ Интересантне хипотезе засноване на вишестраној анализи предлаже проф. Р. Флора. Cf. ор. сit., стр. 243-244.

${ }_{60}$ Принципијелно, апсолутна негација аутентичности Асакијеве тврдње била би њено одбацивање од стране самог Вука и, обратно, апсолутна потврда - њено потврђење од самог Вука. Како је сасвим очекивано да се Вук није упознао са Асакијевим списима, он, према томе, није ни имао како да их потврди или одриче. Сваки други доказ, укључив и доказивање да се Вук интересовао за румунски фолклор или је имао збирку румунског фолклора, не би имао апсолутну снагу, све док се не би даље доказало да је Вук такву збирку поклонио Асакију. По оцени Н. Јорге - за коју не налазимо никакву мотивацију, осим оне коју наводи Р. Флора, ор. сit., стр. 237 да Вук није могао уступити Асакију своју збирку без копије - Асаки је преписао наводни румунски фолклор из Вукове бележнице. Cf. N. Iorga, Balada populara româneasca. Originea si ciclurile ei, Valeniide-Munte, 1910, стр. 11; Idem, Istoria literaturii românešti, I, II издање, Букурешт, 1925, стр. 32. (Ап. Р. Флора, ор. cit., стр. 237, фуснота бр. 8). Јоргина оцена се противи Асакијевом наводу. Ипак, да је тачна, онда у Вуковој оставштини би требало да се сачува оригинал, што, међутим није случај. 
ску-а и Г. Сиона. Оне први пут привлаче у сферу научних испитивања код Румуна Вукова дела, и то народне песме. После тога, српске баладе постају стално присуство у румунској фолклористци. Њихова припадност истој југоичточно-европској фолклорној зони, којој припадају и румунске народне баладе, мноштво заједничких личности ${ }^{61}$, мотива и других елемената ${ }^{62}$, чини немогуће свако упоредно испитивање румунске народне поезије у којем не би се узимале у обзир и српске народне песме. Као израз растућег интереса Румуна према српској народној поезији бележима, у првој половини XX века, студије неких фолклориста, као што су Јосиф Поповићи ${ }^{63}$ и А. Белота ${ }^{64}$, посвећене појединим циклусима српских балада.

Први преводи српских народних песама на румунски јављају се такође из потребе научне аргументације. У поменутој студији, Г. Сион преводи, по Дозону, Бој на Косову ${ }^{65}$, а касније Александри и Г. Дем. Теодореску - Зидағе Скадра. ${ }^{6}$ Исто из научних потреба су настали и Наsdeu-ови преводи у његовој опширној студији о Негру-Вода, објављеној у уводу

${ }^{61}$ Кратак списак тих личности види код. Р. Флоре, op. cit., стр. 244-245, где се наводи и одређена литература.

${ }^{62}$ Године 1972, у Панчеву, одржан је симпозијум посвећен српско (југословенско)-румунским узајамностима у области народне књижевности. Дајемо неколико наслова саопштења посвећених тој теми: Dan Simonescu, Studiile lui Anton Balota referitoare la relatiile folclorice sîrbo-române, Илија Николић, Влашка земља у народној поезији Јужних Словена, Драгољуб Новаков, Каравласи и каравлашки код Вука Караџића, Миодраг Б. Стојановић, Српско-румунске верзије баладе о продатој невести, Mircea Anghelescu, Variante românešti albe baladei lui Doncila I. C. Chitima, Balada Doicin bolnavul în folclorul sîrbocroat ši românesc, Вукосава Карановић, Лик Влахиње у народној поезији источне Сpбије, Владан Недић, Војвода Мирчета и Радул-бег у српскохрватском народном песништву, Лепосава Ст. Павловић, О неким варијантама о болном Дојчину, George Muntean, Motivul constructiei (homo aedificans) in literaturile zonei carpatobalcanice, Dumitru Pop, Cu privire la influenta baladei populare sud-dunarene asupra baladei populare românešti, Cristen Sandu, Radu (1) voievod în folclorul românesc, sirbešc si bulgaresc и dr. Cf. Societatea de limba româna din P.S.A. Voivodina, Un deceniu de activitate (1962-1972), Зрењанин, 1972, стр. 70-74.

${ }^{63}$ Cf. Iosif Popovici, Kosopolye. Ciclul cîntecelor sîrbešti referitoare la batalia de la Cîmpia Mierlei, „Semenicul” бр. 9 од 15. септембра 1928, стр. 16-24. Кратке оцене тог чланка види код Д. Макреа, Јосиф Поповић, „Cercetari de lingvistica”, Клуж, XV (1970), бр. 2, стр. 213-230.
64 Cf. Дан Симонеску, op. cit.
${ }^{65}$ С. И. Талош, ор. cit.
66 Види горе. 
свог монументалног речника ${ }^{67}$. Иначе, у свом часопису „Traian”68, Hasdeu је већ раније објавио, заједно са уводном студијом, 16 песама из циклуса о Краљевићу Марку, у преводу Дионисие Мирона ${ }^{69}$. У листу „Тимпул” из $1880^{70}$, М. Еминеску репродукује Hasdeu-ов чланак из „Traian”-a, а уз њега неке од Миронових превода, којима додаје нове преводе, чији је преводилац непознат ${ }^{71}$. Преводе песама Ђурђе Смедереваи и Марко Краљевић Еминеску ће касније прештампати из „Тимпул”-а у „Fîntîna Blanduziei”"2. Одломци или песме у целини настављају да се објављују до данас у различитим студијама или публикацијама, тако да су временом преведене на румунски скоро све репрезентативне српске народне епске песме ${ }^{73}$. Издавачко предузеће у Букурешту „Univers” припрема издавање прве збирке у избору једног фолклористе (Octav Paun) и књижевном преводу испробаног посеника на таквом послу (N. Gramescu).

Вукове Српске народне приповетке су нешто касније од песама ушле у саобраћај код Румуна. Први до сад познати преводи датирају од 1878. Ради се о приповеткама Девојка која је вештија од коюа и Зашто је човечији табан издубљен, објављеним у часопису „Трансилванија”. 74 Превод je обавио, изгледа по немачком оригиналу, I. G. Baritiu. ${ }^{75}$ Прво значајније присуство Вукове збирке у научним истраживањима сусрећемо у делу L. Saineanu-a, Basmele române, în comparatie cu legendele antice clasice si în legatura $\mathrm{cu}$ basmele popoarelor învecinate si ale tuturor popoarelor romanice, ${ }^{76}$ Букурешт, 1895 . Вукове заслуге се истичу у самом предговору тог опширног и важног рада румунског филолога, а његово име се често наводи у фуснотама текста. Иначе су српске народне приповетке које је Вук сабрао биле нешто срећније од његових песама: На основу Вукових приповедака састављена је и објављена 1965. антологија српскохрват-

${ }^{67}$ Etimologicum magnum Romaniea, Букурешт, 1887 и следеће.

${ }^{68} \mathrm{I}, 6 \mathrm{p} .50$, од 26 августа 1869.

${ }^{69}$ Cf. Вукосава Карановић, ор. cit.; Г. Михаила, ор. cit.

${ }^{70}$ Cf. 6p. 47-74.

${ }^{71}$ Види Г. Михаила, op. cit.

${ }^{72}$ Idem, ibidem; Sf. „Fintina Blanduziei”, бp. 2 за 1889.

${ }^{73}$ Cf. Victoria Frîncu, Traduceri din literatura populara sîrba în ziarele ši revistele românešti din secolul XIX, где ce аутор задржава и на квалитету превода. Резиме тог саопштења види у књизи, Симпозијум о српско (југословенско) -румунским узајамностима у области народне књижевности, Саопштења (резимеи), Панчево, 28. IX - 1. X. 1972.

${ }^{74}$ XI, 1878, стр. 137-138.

${ }^{75}$ Cf. I. Taloš, op. cit.

76 „Румунске народне приповетке у поређењу са класичким античким легендама и са народним преповеткама суседних народа и свих романских народа”. 
ских народних песама, ${ }^{77}$ а из антологије неке су приповетке прештампане у друге збирке. ${ }^{78}$

Од лингвистичких Вукових радова - као што је и очекивано - пажњу специјалиста је привукао његов Српски рјечник. Њега помиње већ Асаки 1848., касније, 1864., Tincu Velea, ${ }^{79}$ а интензивније почиње да се употребљава приликом израде речника румунског језика, израђених на научној основи, у којима се упућује и на етимологију речи. Навели би-смо речнике A. de Ćihac-a, ${ }^{80}$ B. P. Hasdeu-a, ${ }^{81}$ L. Saineanu-a, ${ }^{82}$ H. Tiktin-a, ${ }^{83}$ Академијин речник ${ }^{84}$ и др. Такође, развој румунске филологије уопште и румунске славистике посебно, довели су до шире употребе Вуковог Српског рјечника за навођење поузданог и народног материујала из српско-хрватске лексике. ${ }^{85}$

Из перспективе Вукових односа са Румунима и Румунијом интересантно би било разматрати и друге аспекте као што су Вукова путовања у Банат, његов однос према румунском језику и румунским питањима, његови пренумеранти Румуни, преписка са Румунима; и друго, али то излази из круга нашег саопштења. ${ }^{86}$

У закључку онога што смо до сада рекли, прихваћање Вукових дела код Румуна било је нешто касније неголи њихово прихваћање у средњој Европи. Али је оно трајно, солидно, свестрано. Предлажући Румунима изабрану руковет лепота српског народног стваралаштва и језика, Вуково дело истовремено им помаже у тумачењу, разумевању и оцењивању сопствених лепота, пребацујући преко минулих векова мост који многобројним нитима спаја две духовне културе, српску и румунску.

77 Basme sîrbo-croate, избор и предговор Дорин Гамулеску, превод Дорин Гамулеску и М. Севастос, Букурешт, 1965.

${ }^{78}$ Као, нпр., у недавно изашлој збирци у „Editura Tinereretului” Povesti nemuritoare, бp. 8; сf. стр. 38-107.

${ }^{79}$ Cf. I. Taloš, op. cit.

${ }^{80}$ Cf. A. de Cihac, Dictionnaire detymologie daco-romane. II. Elements slaves, magyares, turcs, grecs-moderns et albanais, Francfort sur Main, 1879.

${ }^{81}$ Etymologicum magnum Romaniae. Dictionarul limbei istorice si poporane a românilor, Букурешт, I-III (1887), III (1893).

${ }^{82}$ Dictionar universal al limbei române, VII прегледано и допуњено издање Scrisul românesc, Craiova, s. a. (I Издање, 1896).

${ }^{83}$ Cf. H. Tiktin, Rurnänisch-deutsches Wörterbuch. Dictionar român-german, том. I-III, Букурешт, 1897-1925.

${ }^{84}$ Academia Româna, Dictionarul limbii române, Букурешт, 1913-1948.

${ }_{85}$ О значају лексикографског дела Вука Караџића за Румуне, исп. Р. Флора, op. cit., стр. 247-249.

86 Неке податке о томе види код Р. Флора ор. cit., и М. Георгијевић op. cit., Међутим и у том правцу су потербна нова, детаљнија испитивања. 